\title{
Survey, documentation and identification of entomofauna of cocoa, Theobroma cacao L. in major cocoa growing regions of South India
}

\author{
S. Srinivasnaik ${ }^{1 *}$, M. Suganthy ${ }^{2}$, S. Mohan Kumar ${ }^{3}$ and V. Jegadeeswari ${ }^{4}$ \\ ${ }^{1}$ Department of Agricultural Entomology, CPPS, Tamil Nadu Agricultural University (TNAU), Coimbatore- \\ 641003 (Tamil Nadu), INDIA \\ ${ }^{2}$ Department of Medicinal and Aromatic Crops, TNAU, Coimbatore- 641 003(Tamil Nadu), INDIA \\ ${ }^{3}$ CPMB\&B, TNAU, Coimbatore- 641003 (Tamil Nadu), INDIA \\ ${ }^{4}$ Department of Spices and Plantation Crops, TNAU, Coimbatore- 641003(Tamil Nadu), INDIA \\ *Corresponding author. E-mail: sabhavats1@gmail.com \\ Received: November 09, 2015; Revised received: June 08, 2016; Accepted: August 02, 2016
}

\begin{abstract}
Survey, monitoring and documentation of entomofauna of cocoa was carried out in three cocoa growing states viz., Tamil Nadu, Kerala and Andhra Pradesh during 2014-2015. Results revealed that a total number of 23 species of insect pests and 13 species of natural enemies were documented and identified. Among the insect pests, 14, 2 and 7 species were sucking pests, borers and defoliators, respectively. Among the natural enemies, 7 species of predators and 6 species of parasitoids were documented and identified on different insect pests of cocoa. Among the insect pests, sucking pests were found to be predominant and maximum number of entomofauna were recorded in major coco growing areas of Tamil Nadu. From the results it was concluded that the list of entomofauna documented can enhance the knowledge on diversity of the entomofauna associated with cocoa in three different cocoa growing states. Sucking pests were found to be predominant and caused huge yield loss in Tamil Nadu and Kerala. While in Andhra Pradesh pod borer and bark eating caterpillar were found to be predominant causing severe yield loss. This information provides a base for development of location specific Integrated Pest Management module.
\end{abstract}

Keywords: Cocoa, Documentation, Identification, Insect pests, IPM, Natural enemies, Survey

\section{INTRODUCTION}

Cocoa (Theobroma cacao L.) is one of the greatest treasurers ever discovered by man. It is the only source of chocolate and is a rich source of sensory pleasure and energy, adored by almost everyone. It is the third important beverage crop next to coffee and tea, and is the third highest traded commodity in the world. It is one of the world's most valuable crops playing an important role in socio economic life of more than 5 million households. Cocoa is cultivated worldwide over an area of 8.2 million hectares in fifty eight nations and the top five producers account for over 70 per cent of the total production (Prasannakumari et al., 2012).

Globally 43.55 lakh metric tonnes of cocoa has been produced during 2014. Ivory Coast, Ghana and Indonesia are the largest cocoa producing countries with the share of 34, 24 and 14 per cent of the world total production, respectively (ICO, 2014). In India, cocoa cultivation is largely confined to southern states viz., Kerala, Karnataka, Tamil Nadu and Andhra Pradesh. Cocoa is usually planted as inter crop in coconut and arecanut plantations. India ranks eighteenth among the countries cultivating cocoa having an area of 71,000 hectares with a production of 15,000 metric tonnes and productivity of 0.2 met- ric tonnes, of which Tamil Nadu covers an area of 24,000 hectares with a production of 1,100 metric tonnes. Kerala is leading in the production with a share of 41.72 per cent followed by Andhra Pradesh (37.08 per cent), Karnataka (13.90 per cent) and Tamil Nadu (7.28 per cent) (IHD, 2014).

Documentation of entomofauna through survey and monitoring will pave a way to understand taxonomically diversified crop pests, feeding behaviour and their biology. This information will help to formulate reliable integrated pest management module for the management of insect pests of cocoa. With this background the present investigation on survey and documentation of entomofauna of cocoa was undertaken in three states of South India viz., Tamil Nadu, Kerala and Andhra Pradesh.

\section{MATERIALS AND METHODS}

Survey and documentation of entomofauna: Survey, monitoring and documentation of entomofauna of cocoa was carried out in three cocoa growing states of South India viz., Tamil Nadu, Kerala and Andhra Pradesh. Survey was carried out in well-established and high yielding cocoa plantations in Coimbatore district of Tamil Nadu, Palakkad district of Kerala and West and East Godavari districts of Andhra Pradesh to document the entomofauna 
associated with cocoa (Table 1). Entomofauna of cocoa were monitored in three farmer's holdings at Sethumadai and in coconut nursery, TNAU, Coimbatore from October, 2014 to April, 2015. Documented entomofauna were compared among the places surveyed and the results were given below.

Morphological identification of entomofauna: Entomofauna observed during survey and monitoring were collected and brought to the Department of Agricultural Entomology, Centre Plant Protection Studies, TNAU, Coimbatore. Soft bodied insects were preserved in 70 per cent ethanol and other entomofauna were card mounted or pinned. The specimens were identified morphologically by the well known taxonomists viz., Dr. C.A. Viraktamath, Dr. S. Manickavasagam, Dr. M. Ganeshkumar, Dr. N. Chitra and by comparing the specimens in the Biosystematics Laboratory, Department of Agricultural Entomology, TNAU, Coimbatore. The diversity of entomofauna documented in the three states was compared and species richness was analyzed. Economically important pests and natural enemies associated with cocoa in different locations were documented.

\section{RESULTS AND DISCUSSION}

Survey and documentation of entomofauna: From the results of present study on survey and monitoring of entomofauna of cocoa in the farmer's holdings and coconut nursery, the observed entomofauna were cate- gorized into two groups viz., insect pests and natural enemies. A total number of 23 species of insect pests and 13 species of natural enemies were documented. Among the insect pests, 14, 2 and 7 species were grouped under sucking pests, borers and defoliators, respectively. Among the natural enemies, 7 species of predators and 6 species of parasitoids were documented on different insect pests of cocoa (Table 2).

Among the sucking pests, two species of tea mosquito bugs, five species of mealybugs, two species of aphids, three species of plant hoppers, one species of scale insect and one species of cowbug were found to suck the sap from different parts of cocoa viz., leaves, tender shoots, flowers, flower cushions, cherelles and pods. Bark eating caterpillar and pod borer were the two borers found to infest different parts of cocoa tree. Among the two borers, bark eating caterpillar occurred regularly and caused upto 40 per cent damage to cocoa trees. Four species of hairy caterpillars, one species of bagworm, one species of ash weevil and one species of grasshopper were the defoliators found feeding on cocoa leaves (Table 2).

Among the tea mosquito bugs, Helopeltis bradyi was noticed in Tamil Nadu, Kerala and Andhra Pradesh, whereas, H. antonii was found in Tamil Nadu and Kerala. Among the farmer's holdings surveyed, $H$. bradyi was found to be the predominant species over H. antonii. Among the mealybugs documented, Planococcus citri and Paracoccus marginatus were docu-

Table 1. Details of farm holdings surveyed and monitored for the documentation of entomofauna of cocoa during 2014-2015

\begin{tabular}{|c|c|c|c|c|}
\hline S. No. & Location & $\begin{array}{c}\text { Name of the farmer/ } \\
\text { farm }\end{array}$ & Address of the farmer/farm & $\begin{array}{l}\text { Age of the } \\
\text { plantation }\end{array}$ \\
\hline $\mathrm{I}$ & Tamil Nadu & & & \\
\hline 1 & & VJ. Jayaraj & Sethumadai, & 10 years \\
\hline 2 & Sethumadai & VJ. Prasad & Pollachi taluk, & 15 years \\
\hline 3 & & Rajaram & Coimbatore district & 10 years \\
\hline 4 & Coimbatore & Coconut nursery & TNAU, Coimbatore & 4 years \\
\hline II & Kerala & & & \\
\hline 5 & Chamanampathy & T.S. Asokan & Chamanampathy, Palakkad district & 15 years \\
\hline III & Andhra Pradesh & & & \\
\hline 6 & & A. S. Pratap & Naguldenipadu, Eluru & 17 years \\
\hline 7 & & Gopinathreddy & Singarayapalem, T. Narasapuram & 21 years \\
\hline 8 & & Thirumurthirao & Singarayapalem, T. Narasapuram & 13 years \\
\hline 9 & & Rajanbabu & Vijaya gardens, Eluru & 20 years \\
\hline 10 & & Gopalakrishanan & Pedavegi, Eluru & 17 years \\
\hline 11 & & GP Rao & Eluru & 18 years \\
\hline 12 & & Sathish & Vundrajavaram, Eluru & 18 years \\
\hline 13 & & Shivananda & Savaram, Eluru & 18 years \\
\hline 14 & West Godavari & Ravi Prasad & Savaram, Tanuku & 6 years \\
\hline 15 & & Ramakrishanaraju & Velayaduru, Tanuku & 13 years \\
\hline 16 & & Muraliraju & Velayaduru, Tanuku & 19 years \\
\hline 17 & & Narayanaraju & Velayaduru, Tanuku & 17 years \\
\hline 18 & & Sremannarayanrao & Velayaduru, Tanuku & 19 years \\
\hline 19 & & Shankararao & Bapiraju gudam, Eluru & 20 years \\
\hline 20 & & Hari Mohan & Kunchum padi, Eluru & 22 years \\
\hline 21 & & Krishnabhaskar & Badarada, Eluru & 20 years \\
\hline 22 & & Subbaraju & Lakshmipuram, Eluru & 15 years \\
\hline 23 & East Godavari & Madhusudanrao & Vearavaram, Rajhamandry & 14 years \\
\hline
\end{tabular}


S. Srinivasnaik et al. / J. Appl. \& Nat. Sci. 8 (3): 1444 - 1451 (2016)

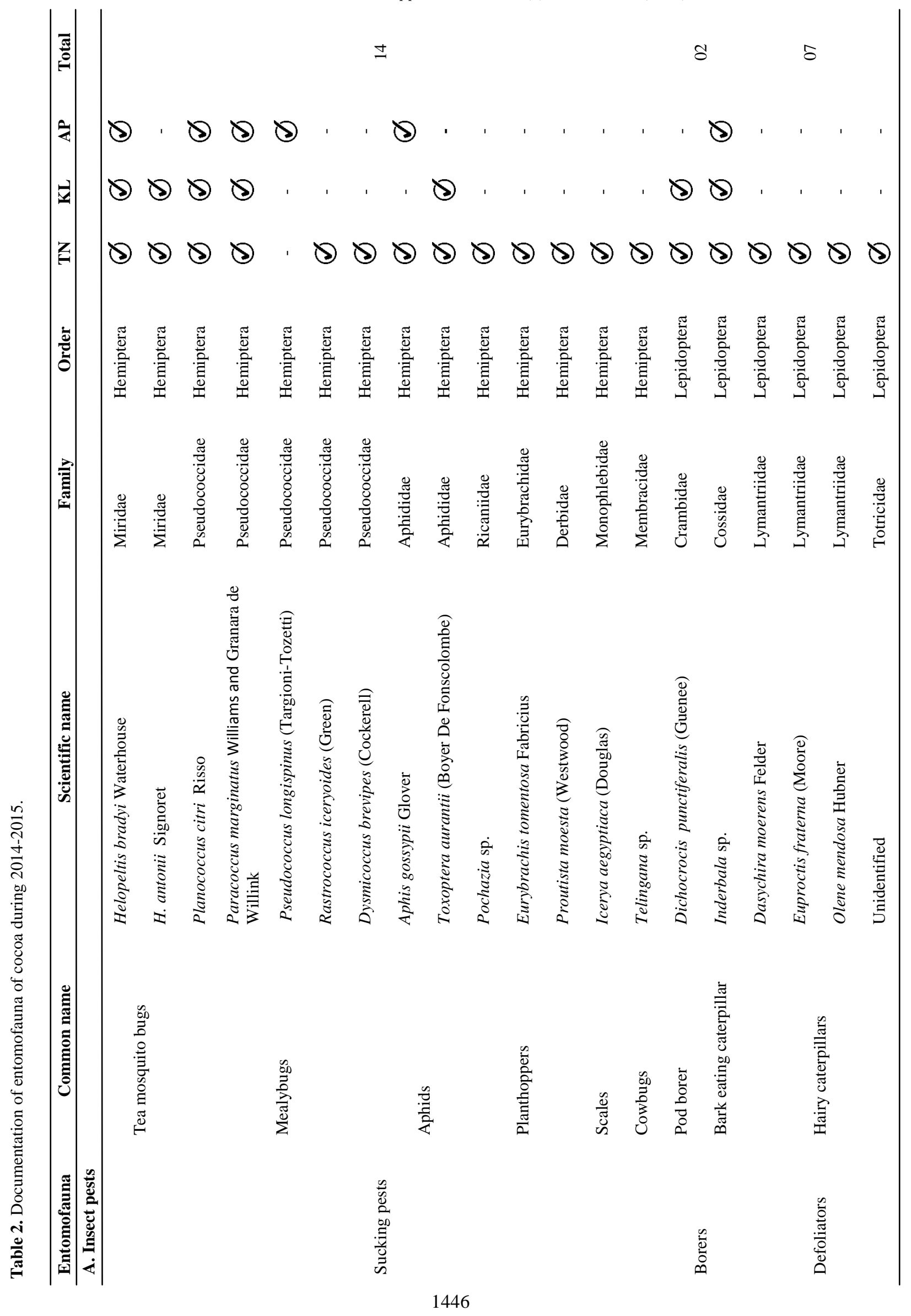


S. Srinivasnaik et al. / J. Appl. \& Nat. Sci. 8 (3): 1444 - 1451 (2016)

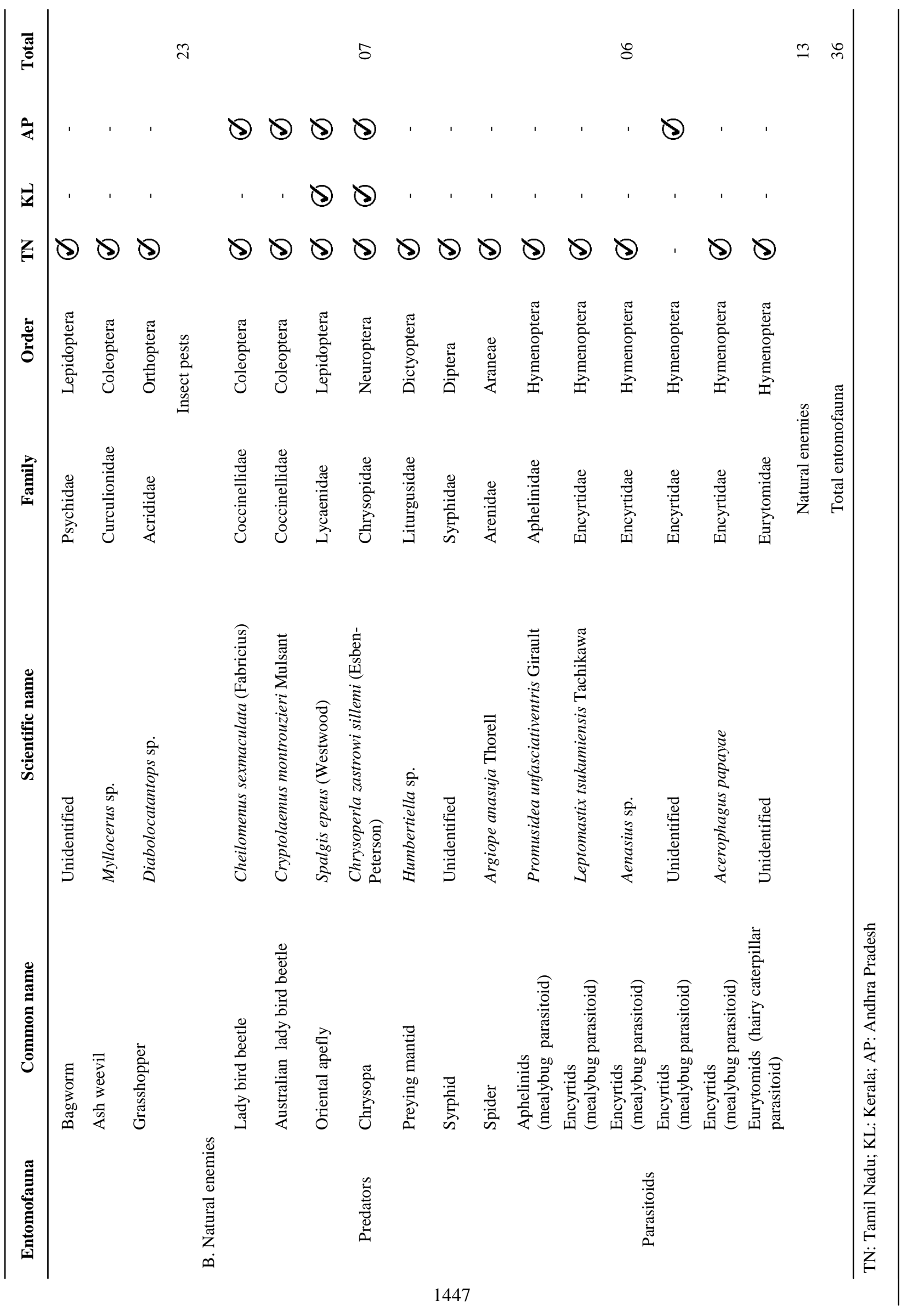


mented in all the three states, whereas, Pseudococcus longispinus was observed only in Andhra Pradesh. Rastrococcus iceryoides and Dysmicoccus brevipes were documented only in Tamil Nadu (Table 2).

Among the aphids, Aphis gossypii was documented in Tamil Nadu and Andhra Pradesh, whereas, Toxoptera aurantii was observed in Kerala and Tamil Nadu. All the planthoppers, scales, cowbugs, defoliators, bagworms, ash weevils and grasshoppers were observed only in Tamil Nadu, whereas, pod borer was recorded in

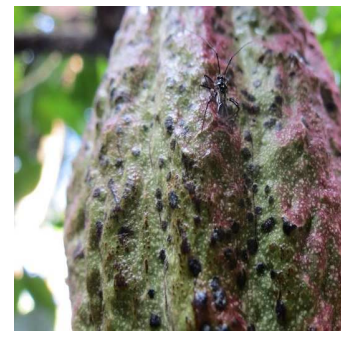

Helopeltis bradyi

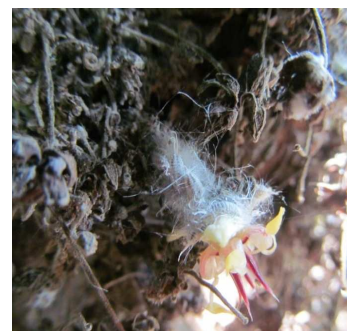

Pseudococcus longispinus

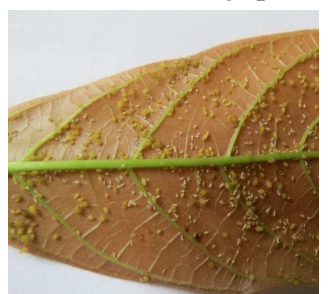

Aphis gossypii

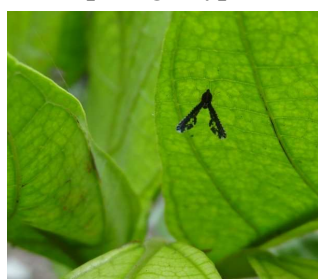

Proutista moesta

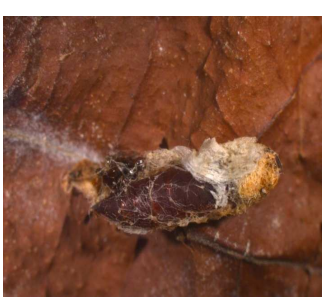

Pupa of $D$. punctiferalis

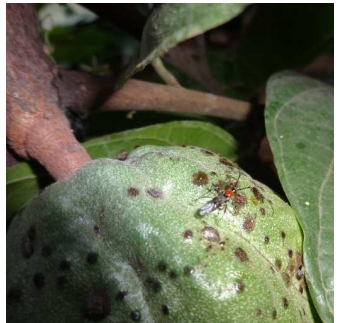

H. antonii

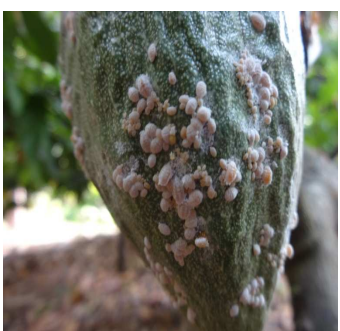

Rastrococcus iceryoides

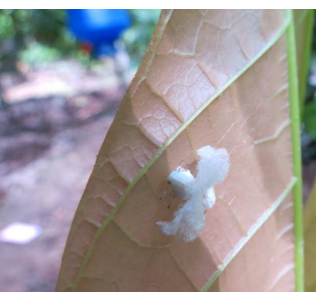

Nymph of Pochazia sp.
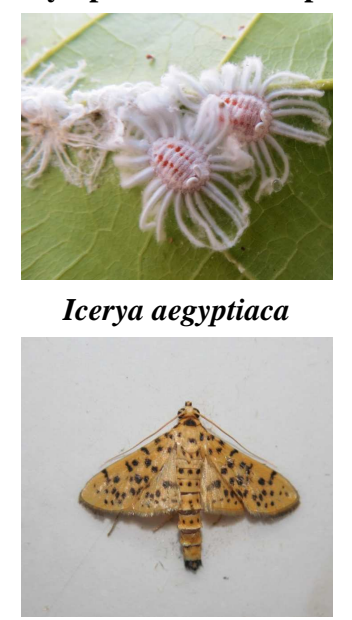

Adult of $D$. punctiferalis
Kerala and Tamil Nadu. Bark eating caterpillar was recorded as a major pest in all the three cocoa growing states (Table 2).

Thirteen species of natural enemies viz., seven species of predators and six species of parasitoids were documented. Among the seven predators, two species of coccinellids, one species of lycaenid, one species of chrysopid, one species of liturgusid, one species of syrphid and one species of arenid were found to be associated with cocoa pests. Out of six parasitoids

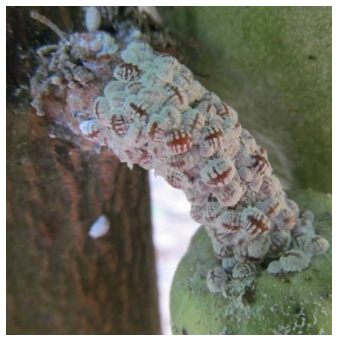

Planococcus citri

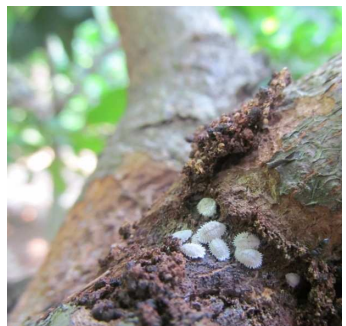

Dysmicoccus brevipes

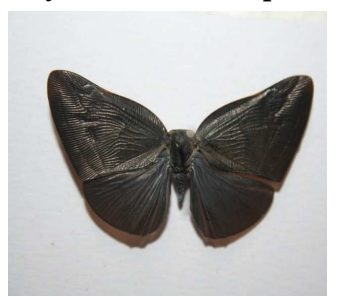

Adult of Pochazia sp.

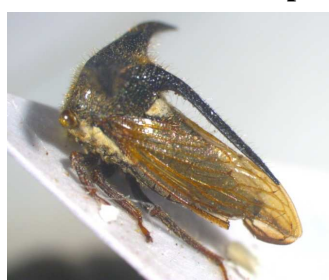

Telingana sp.

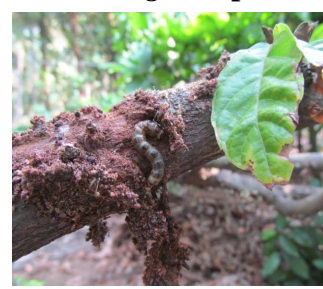

Larva of Inderbala sp.

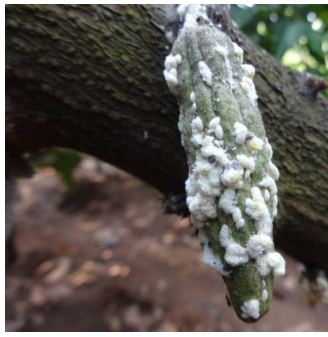

Paracoccus marginatus

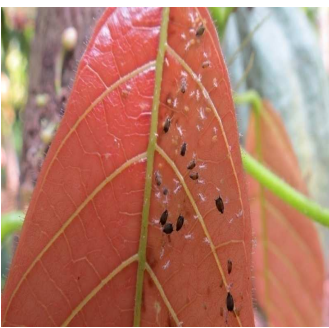

Toxoptera aurantii

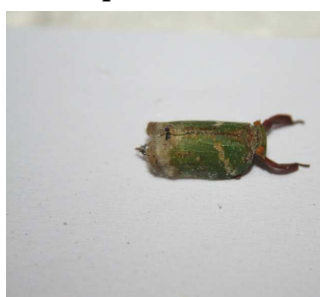

Eurybrachis tomentosa

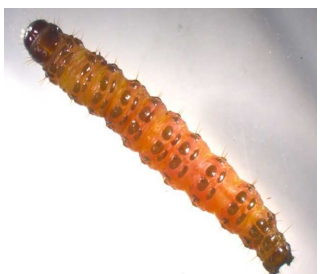

Larva of $D$. punctiferalis

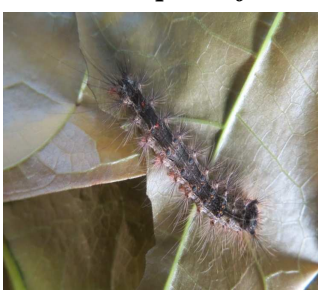

Larva of D. moerens
Contd....... 
S. Srinivasnaik et al. / J. Appl. \& Nat. Sci. 8 (3): 1444 - 1451 (2016)

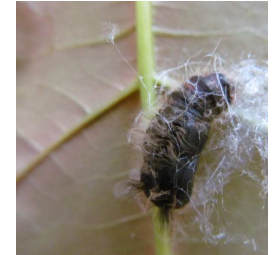

Pupa of $D$. moerens

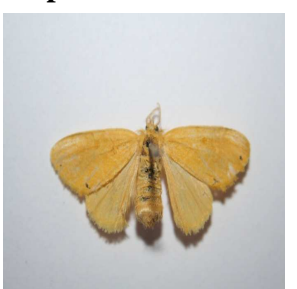

Adult of E. fraterna

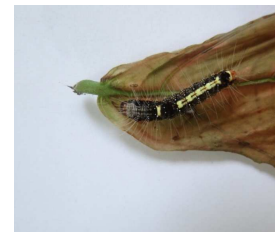

Larva of tortricid

(Unidentified)

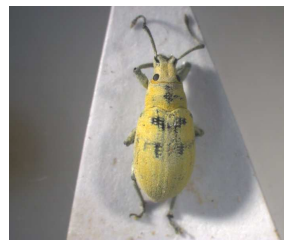

Myllocerus sp.

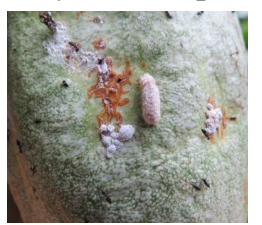

Larva of Spalgis speus

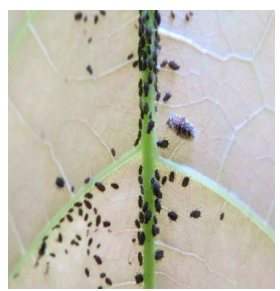

Grub of syrphid

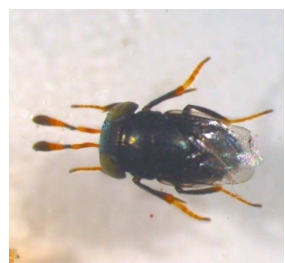

Aenasius sp.

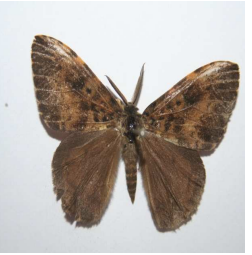

Adult of $D$. moerens

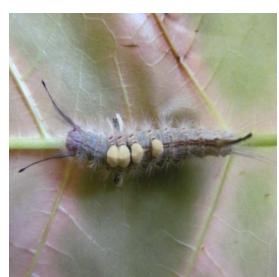

Larva of Olene mendosa

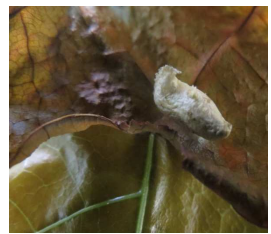

Pupa of tortricid

(Unidentified)

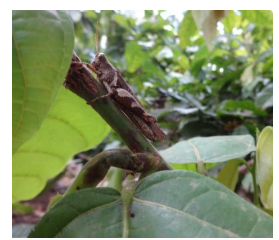

Diabolocatantops sp.

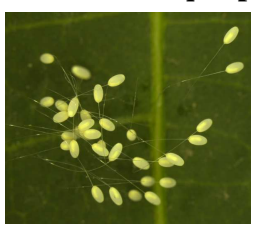

Eggs of Chrysoperla zastrowi sillemi

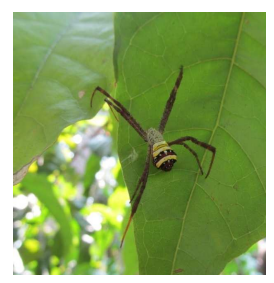

Argiope anasuja

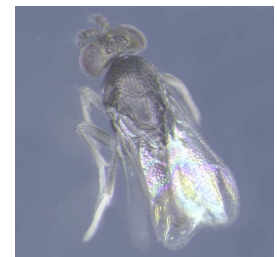

Encyrtid (Unidentified)

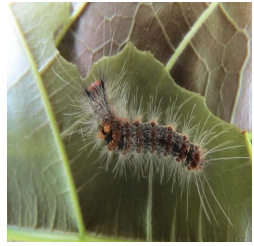

Larva of E. fraterna

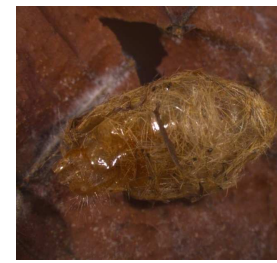

Pupa of $O$. mendosa

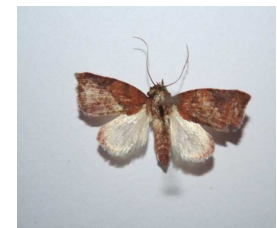

Adult of tortricid
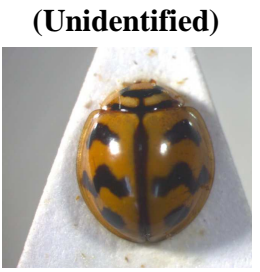

Cheilomenus sexmaculata

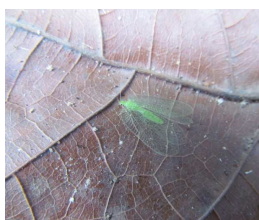

Adult of C. zastrowi sillemi

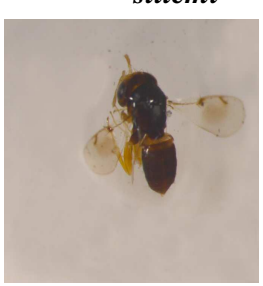

Promusidea unfasciativentris

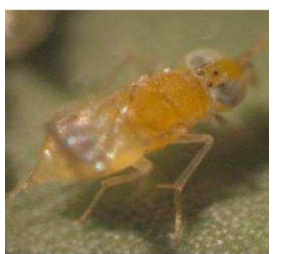

Acerophagus papayae

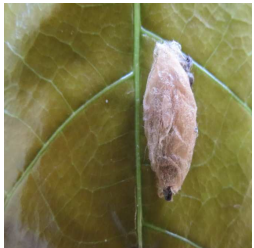

Pupa of E. fraterna

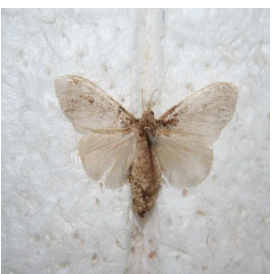

Adult of $O$. mendosa

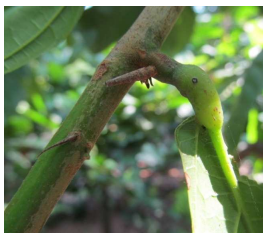

Bagworms

(Unidentified)

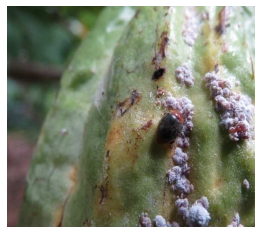

C. montrouzieri

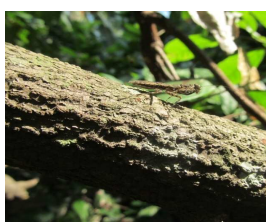

Humbertiella sp.

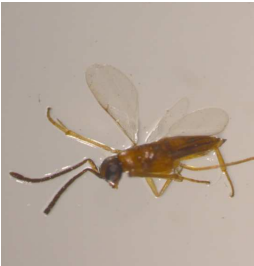

Leptomastix tsukumiensis

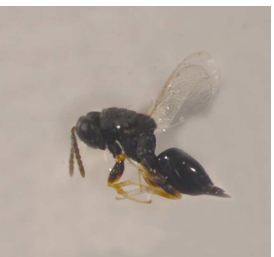

Eurytomid (Unidentified)

Fig.1. Morphological identification of entomofauna of cocoa. 
documented, four species of encyrtids and one species of aphelinid parasitized mealybug, $P$. citri and a eurytomid parasitoid was documented on hairy caterpillar, Dasychira moerens (Table 2).

Among the predators, oriental apefly and chrysopa were recorded in all the three states, while, lady bird beetles were documented in Andhra Pradesh and Tamil Nadu. Preying mantids, syrphids and spiders were observed only in Tamil Nadu. Except an encyrtid parasitoid observed in Andhra Pradesh, all other parasitoids were observed in Tamil Nadu (Table 2). Prasannakumari et al. (2012) also reported that red borer (Zeuzera coffeae), tea mosquito bug (Helopeltis antonii), mealybugs (Planococcus lilacinus), ash weevil (Myllocerus sp.), cockchafer beetle (Leucopholis sp.), red banded thrips and storage pests (Corcyra cephalonica) were the major pests on cocoa in Kerala, Andhra Pradesh, Tamil Nadu and Karnataka regions in India.

Among the insect pests documented, sucking pests were found to be predominant. This might be due to the congenial tree environment with high temperature and low humidity prevailing in the cocoa ecosystem for the development of sucking pests. The results are in accordance with the findings of Jamunadevi (2010) who has reported that the highest number of aphids and mealybugs were present in aonla ecosystem in Tamil Nadu.

$P$. citri, $P$. marginatus, $P$. longispinus, $R$. iceryoides and $D$. brevipes were the five different mealybugs documented during survey. Strickland (1951), Dale (1962), and Attafuah et al. (1963) also reported more than 20 species of mealybugs infesting cocoa in West Africa. Among them, $P$. citri, $P$. lilacinus, $P$. njalensis, Ferrisia virgata and Psuedococcus adonidum were found to be major (Prasannakumari et al., 2012) and associated with swollen shoot viral disease of cocoa.

$H$. bradyi and $H$. antonii were documented in the cocoa plantations surveyed. Among the tea mosquito bugs observed, $H$. bradyi was found to be predominant over $H$. antonii. This observation is in line with Sundararaju (1996) whofound that out of 31 specimens collected from cocoa, 30 were of $H$. bradyi and only one was $H$. antonii. Leston (1970) also reported 3 groups of the cocoa capsids causing damage to cocoa in Tamil Nadu.

Dasychira moerens, Euproctis fraterna, Olene mendosa, torticid (unidentified), psychid (unidentified), Myllocerus sp. and Diabolocatantops sp. were the defoliators documented in cocoa. Alibert and Les (1951), Szent-Ivany (1964) and Smith (1965) also reported 56 genera of beetles and 147 species of lepidopterans to be associated with cocoa in West Africa.

During the survey, Cheilomenus sexmaculata, Cryptolaemus montrouzieri, Spalgis epeus, Chrysoperla zastrowi sillemi, Humbertiella sp.,syrphid (unidentified) and Argiope anasuja were documented as major predators and Promusidea unfasciativentris, Leptomastix tsukumiensis, Aenasius sp., encyrtid parasitoid (unidentified), Acerophagus papayae and eurytomid (unidentified) were documented as parasitoids in cocoa ecosystem to know the species diversity of natural enemies and for the development of IPM module using these biocontrol agents. Similar results were reported by BoukhrisBouhachem (2011) who has recorded 16 natural enemies on citrus aphids in Tunisia. Among them, coccinellids (Coccinella septempunctata, Scymnus subvillosus, Adalia bipunctata, Chilocorus bipustulatus and Hippodamia variegate) were the predominant predators, followed by a cecidomyiid (Aphidoletes aphidimyza), a chrysopid (Chrysoperla carnea) and a syrphid (Episyrphus balteata). According to BoukhrisBouhachem (2011), parasitoids viz., Aphidius matricariae, A. colemani, Ephedrus persicae, Lysiphlebus fabarum, L. testaceipes, Praon volucre, Trioxys angelicae and Diaeretiella rapae played significant role in reducing citrus aphid population.

Morphological identification of entomofauna : Results of morphological identification of entomofauna of cocoa to study the identifying the species diversity revealed that the two species of tea mosquito bugs were identified as Helopeltis bradyi Waterhouse (Plate 18) and H.antonii (Miridae: Hemiptera) based on the key given by Stonedahl (1991) as detailed below.

Base of hind femur with broad pale band, distal region usually fuscous; length of antennal segment I much greater than posterior width of pronotum (ratio: males, 1.50:1-1.85:1; females, 1.45:1-1.60:1); lobal sclerite with limited scattered tubercles at apex only; sclerotized rings of genital chamber fused posteriorly.

Basal third and apex of hind femur mostly fuscous, middle section pale with fuscous spots or mottling; length of antennal segment I slightly greater than posterior width of pronotum (ratio: males, 1.20:1- 1.45:1; females, 1.05:1-1.30:1); lobal sclerite with dense distribution of tubercles distally, usually extending proximally along outer margin to near median level of sclerite; sclerotized rings of genital chamber not fused posteriorly.

Five species of mealybugs were morphologically identified as Planococcus citri Risso, Paracoccus marginatus Williams and Granara de Willink, Pseudococcus longispinus (Targioni-Tozetti), Dysmicoccus brevipes (Cockerell) and Rastrococcus iceryoides (Green) (Pseudococcidae: Hemiptera). Two species of Aphids were identified morphologically as Toxoptera aurantii (Boyer De Fonscolombe) and Aphis gossypii Glover (Aphididae: Hemiptera), three species of Planthoppers as Pochazia sp. (Ricaniidae: Hemiptera), Eurybrachis tomentosa Fabricius (Eurybrachidae: Hemiptera) and Proutista moesta (Westwood) (Derbidae: Hemiptera), one species of Scale insect as Icerya aegyptiaca (Douglas) (Monophlebidae: Hemiptera) and one species of Cowbug/Tree hopper as Telingana sp. (Membracidae: Hemiptera) (Fig.1).

Among the borers, Pod borer was identified morphologically as Dichocrocis punctiferalis (Guenee) (Crambidae: 
Lepidoptera) and Bark eating caterpillar as Indarbela sp. (Cossidae: Lepidoptera). The Defoliators viz., Hairy caterpillars were identified as Dasychira moerens Felder (Lymantriidae: Lepidoptera), Euproctis fraterna (Moore) (Lymantriidae: Lepidoptera), Olene mendosa Hubner (Lymantriidae: Lepidoptera) and Tortricid (unidentified) (Tortricidae: Lepidoptera). While, Ash weevils were identified as Myllocerus sp. (Curculionidae: Coleoptera), bagworm as Psychid (unidentified) (Psychidae: Lepidoptera) and Grasshopper as Diabolocatantops sp. (Acrididae: Orthoptera) (Fig.1).

The predators of insect pests of cocoa were morphologically identified as Cheilomenus sexmaculata (Fabricius) (Coccinellidae: Coleoptera), Cryptolaemus montrouzieri Mulsant (Coccinellidae: Coleoptera), Spalgis epeus (Westwood) (Crambidae: Lepidoptera), Chrysoperla zastrowi sillemi (Chrysopidae: Nueroptera), Humbertiella sp. (Liturgusidae: Dictyoptera), syrphids (unidentified) (Syrphidae: Diptera) and Argiope anasuja (Araneidae: Araneae) (Fig.1).

Parasitoids on mealybugs and Hairy caterpillars were morphologically identified as Promusidea unfasciativentris Girault (Aphelinidae: Hymenoptera), Leptomastix tsukumiensis Tachikawa (Encyrtidae: Hymenoptera), Aenasius sp. (Encyrtidae: Hymenoptera), encyrtid parasitoid (unidentified) (Encyrtidae: Hymenoptera), Acerophagus papayae (Encyrtidae: Hymenoptera) and eurytomid parasitoid (unidentified) (Eurytomidae: Hymenoptera), respectively (Fig.1)

\section{ACKNOWLEDGEMENTS}

The authors are grateful to Mondelez Foods India Private Limited for providing financial support (No. Dean (Hort.)/CBE/ Cocoa - Cadbury scheme/ Student JRF/ Posting order/2015 dt. 20.01.2015) in the form of junior research fellowship to the first author for carrying out the research.

\section{REFERENCES}

Alibert and Les, H. (1951). Insectes vivant surles cacaoyers en Afrique occidentale. Mem. Inst. Frnf. Afriquenoire, Dakar, 15: 1-174.

Attafuah, A. Blencowe, J.W. and Brunt, A.A. (1963). Swollen-shoot diseases of cocoa in Sierra Leone. Trop. Agriculture, 40: 229-232.

Boukhris-Bouhachem, S. (2011). Aphid enemies reported from tunisian citrus orchards. Tunisian Journal of Plant Protection, 6: 21-27.

Dale, W.T. (1962). Diseases and pests of cocoa, a virus disease in agriculture and land use in Ghana. Wills, J.B., Ed., Oxford Univ. Press, London. 286-316 pp.

ICO (2014). Quarterly bulletin of cocoa statistics (International Cocoa Organisation), 33pp.

Indian Horticulture Database. (2014). [Online] Available: http://www.nhb.gov.in/area-pro/NHB_Database.htm (Retrieved on Aug 11, 2015).

Jamunadevi, S. (2010). Arthropod fauna of aonla (Emblica officinalis Gaertn.) ecosystem. M.Sc. (Ag.) Thesis, Tamil Nadu Agricultural University, Coimbatore-3. 60-101pp.

Prasannakumari, S., Vikraman Nair, R., Lalithabai, E.K., Mallika,V.K.,Manimol,J.S., Abraham, K. and Savithri, K.E. (2012). Cocoa in India. Kerala Agricultural University, Directorate of Extension, Mannuthy, Thrissur. 37p.

Smith, M.R. (1965). A list of lepidoptera associated with cocoa in West Africa with notes on identification and biology of species in Ghana. Tech. Bull. Cocoa Research lnstitute, Tafo, 9: 1-68 pp.

Strickland, A.H. (1951). The entomology of swollen shoot of cacao. I. The insect species involved, with notes on their biology. Bulletin of Entomological Research, 41: 725-748.

Sundaraju, D. (1996). Studies on Helopeltis spp. with special reference to $H$. antonii $\mathrm{S}$. in Tamil Nadu. Ph. D Thesis, Tamil Nadu Agricultural University, Coimbatore-3. $201 \mathrm{p}$.

Szent-Ivany, J.J.H. (1961). Insect pests of Theobroma cacao in the Territory of Papua and New Guinea. Papua New Guinea Agricultural Journal, 13: 127-14 